\title{
Developments and Trends of Mergers and Acquisitions in the Energy Industry
}

\author{
Karolis Andriuškevičius * and Dalia Štreimikienė (1) \\ Lithuanian Energy Institute, Breslaujos st. 3, LT-44403 Kaunas, Lithuania; dalia.streimikiene@lei.lt \\ * Correspondence: karolis.andriuskevicius@gmail.com; Tel.: +370-626-98749
}

Citation: Andriuškevičius, K.; Štreimikienè, D. Developments and Trends of Mergers and Acquisitions in the Energy Industry. Energies 2021, 14, 2158. https://doi.org/10.3390/ en14082158

Academic Editor: Fabrizio Ascione

Received: 12 March 2021

Accepted: 9 April 2021

Published: 13 April 2021

Publisher's Note: MDPI stays neutral with regard to jurisdictional claims in published maps and institutional affiliations.

Copyright: (c) 2021 by the authors. Licensee MDPI, Basel, Switzerland. This article is an open access article distributed under the terms and conditions of the Creative Commons Attribution (CC BY) license (https:/ / creativecommons.org/licenses/by/ $4.0 /)$.

\begin{abstract}
Developments, trends, business climate, conditions, factors influencing the efficiency and results of mergers and acquisitions (M\&A) in the energy sector are explored in this research. PESTLE (political, economic, social, technological, legal, environmental) analysis was performed in order to determine the driving forces of M\&As in the energy industry. Considering the motivation and main questions of the study, a sample of global M\&A deals that have occurred during the period 19952020 has been analyzed. DataStream 5.1 database by Thomson Reuters was employed to identify the sample of global energy companies that took over another company in the period 1995-2020. According to the research, while the role and presence of M\&As in the energy industry are increasing, the purpose of the M\&A deals has changed remarkably. During 1995-2010, most M\&A events were conducted in order to explore synergies and benefit from cost reduction. Since the last decade, firms are pursuing M\&As in the search of growth opportunities, ensuring supply and reflecting demand for green development of ecological environment and ongoing changes in the nature of energy.
\end{abstract}

Keywords: mergers and acquisitions (M\&A); energy; development; trends; PESTLE analysis

\section{Introduction}

Already 30 years ago, an empirical observation was made [1] that "over the past 20 years, the minimum company size required to compete successfully in most industry segments has been steadily increasing." Within the content of this assertation is an assumption of growth being a key element for business success and prosperity. Two main paths lead to business growth - either companies grow internally by nurturing within-firm resources and internal investments or firms pursue an external growth strategy and proceed with acquiring other firms. Mergers and acquisitions (hereinafter M\&As) may be defined as transactions between two independent companies when a company (merging company or acquirer) buys either part or the entire company from another company (merged company or acquired company). Even though concepts of merger and acquisition are often used interchangeably, they refer to different agreements and different modes of transactions. A merger occurs when two individual firms combine and turn into a single new company. Following this transaction, shares of each company are surrendered, and shares of a new company are issued instead. On the contrary, an acquisition occurs when a firm buys shares of another and becomes a legal shareholder of the acquired company. From the legal perspective, the acquired firm stops to exist. The bidder takes over the business of the acquired company. Finally, shares of the acquired company stop, while shares of the bidder continue to be traded.

Considering various transformations that are undergoing in the global energy landscape, our research problem addresses developments and trends of M\&As in the energy industry. On the one hand, the paper seeks to determine and reflect on industry changes in the context of addressing the sustainable development concept. On the other hand, our research recognizes that a focus on sustainable development in the energy industry has led to an increase in M\&A activities. 
Although energy needs were modest prior to the industrial revolution, the evolution of the steam engine during the 17th and 18th centuries has opened a world of possibilities. Further, coal-powered steam engines, electric generators, and hydroelectric plants introduced in the 19th century have enhanced accessible energy capacities. Affordable vehicles, the spread of electricity, massive power stations, large coal stations, hydroelectric plants, powerlines, and nuclear power plants were the key driving forces of energy production and accessibility in the 20th century. The study in [2] has studied historical trends of energy consumption and predicted that it is unavoidable for oil, gas, coal, and renewables to account for a quarter of global energy consumption. On the contrary, Cainenga et al. (2016) observe that currently, each of these sectors reflects $32.6 \%, 23.7 \%, 30.0 \%$, and $13.7 \%$ of global energy consumption. Similarly, statistics available on Statista forecasts that global electricity generation is expected to double from 24.77 trillion kilowatt hours in 2018 to 44.26 trillion kilowatt hours in 2050. Most significant is the structural change of renewable sources, which are estimated to generate $49 \%$ of total electricity generation in 2050. In comparison, currently, renewable sources generate $28 \%$ of total electricity generation.

According to the Global Industry Classification Standard (hereinafter GICS), the energy industry consists of firms that are in the business of oil and gas, coal, and other consumable fuels' exploration, production, refining, marketing, storage, and transportation. Many companies in the energy industry have already implemented or are planning to engage in M\&A transactions because they consider M\&As straightforward, and in many cases, less expensive than internal development or strategic alliances. However, empirical studies do not provide consent results and do not unambiguously confirm that M\&A transactions generate economic return. Similarly, an open question remains whether related or unrelated M\&A leads to better results. In addition to growth itself, M\&A transactions in the energy industry seem promising in many cases since they may improve operational efficiencies and analytical capabilities. Issues of operational efficiencies and analytical capabilities are essential and urgent, especially for oil and gas companies, because currently depressed prices mean that profits are hard to come. On the other hand, they are also essential for renewable energy, which has been quite expensive in some cases, because the infrastructure is not in place.

The market for mergers and acquisitions is characterized by waves. Specifically, there are regularly alternating periods of low and high levels of M\&A activities. M\&A wave theory is constructed by two main perspectives-neoclassical and behavioral school of thoughts. Firstly, efficient market premises are attributed to neoclassical theory. Secondly, nonefficient market premises construes behavioral M\&A wave theory. Research of several authors has elaborated on the neoclassical theory. Many scientists [3,4] supported that M\&A are often pursued as a response to external environmental developments (e.g., technology changes, innovations, nationalization, monopolization, liberalization, economic shocks, etc.). M\&As have the capacity to reconfigure resources and improve business efficiency. From the perspective of neoclassical theory, it has been further added [5-7] that M\&A transactions are comparable to capital flows following profit pursuance. Similar to capital flows, M\&A flows choose efficient and high-quality firms in comparison with inefficient and low-quality firms. Further, it has been [8] added that capital liquidity is the driving force of M\&A waves according to neoclassical theory. It has been observed that M\&A activities were increasing during instances of strong and decreasing during periods of low capital liquidity. Several scientists [9-11] have analyzed and supported the behavioral theory. In addition to the corporate executives and corporate management board's opportunistic behavior, the behavioral theory holds the position that waves of M\&As are also caused by misevaluation and overvaluation in the stock market.

Regulatory, economic, and technological changes are causing waves of industry M\&As [5]. It depends on the sufficient capital liquidity whether the regulatory, economic, and technological shocks would lead to an actual M\&A wave [5]. In his empirical research [5], the author has analyzed industries with merger waves. Among other findings, it was found out that the petroleum and natural gas industry has experienced an M\&A 
wave in June 1997, which was caused by price increases, booming petroleum drilling, and cost increases. These developments circumstanced that size of the company affected efficiency level-larger companies were found to be more efficient in comparison with the smaller companies. Similarly, in the utility industry, the M\&A wave was also found to have occurred in November 1997. Wave in the utility sector was caused by market deregulation and cancellation of a law, which prohibited M\&As between noncontiguous companies [5].

In recent years, although M\&A value and volume in the energy industry have increased, there is a knowledge gap in systematic literature review on developments and trends in the industry, especially from methodological and managerial perspectives. The research seeks to overcome this gap and contributes by providing a systematic literature review on developments and trends of M\&As in the energy industry. Two key questions are being raised in the study. Firstly, it asks which political, economic, social, technological, legal, and environmental changes have shaped the landscape industry M\&As. Secondly, questions are being raised about the dynamics of M\&A volume and value and whether M\&As in the energy industry follows wavelike tendencies. The main purpose of the paper is to investigate and discuss M\&A developments and trends in the energy industry with a focus on M\&A dynamics and its driving forces.

Based on various empirical studies, the authors perform a structured literature review and perform a political, economic, social, technological, legal, environmental (hereinafter "PESTLE") analysis, which seeks to critically discuss and evaluate developments and trends of the energy industry M\&A market. Furthermore, a sample of global M\&A deals that have occurred in the energy industry during the period 1995-2020 has been analyzed.

\section{Context}

Looking from a historical perspective, the energy industry has experienced several shocks and consolidation waves. These were caused by geopolitical decisions, fluctuating commodity prices, low economic growth, and cost composition of upstream and downstream sectors of the value chain. Industry consolidation has been ongoing for over four decades and is still evolving [12]. Firstly, major oil price changes in the 1980s and 2000s have significantly affected and stimulated energy business consolidation activities. Secondly, several large-scale M\&A deals were completed in the energy sector as a market response to rising prices of crude oil. Thirdly, recently it became evident that unpredictable oil prices signals the need for further debate about the formation and components of oil prices. Price volatility, increasing production costs throughout the value chain and negative corporate cash flows have increased activity levels in the energy industry. Specifically, the volume of cross-border M\&A events has grown.

M\&As in the energy sector have industry-specific features, e.g., declining levels of accessible oil and gas reserves, nontraditional players (national oil and gas companies, investment management companies, and companies in oilfield services market) entering into the M\&A market, regional consolidation of energy services, initiatives by governments worldwide to promote renewables growth, etc. [13].

In addition to the external circumstances, it shall be observed that consolidation of the energy industry is stimulated by the energy developments itself. M\&A market considers the development of certain areas of the energy sector and establishes which particular subsector is attractive for prospective investors. Therefore, the ongoing changes in the global energy markets influence the valuations and attractiveness of each M\&A deal. Furthermore, considering that the energy industry's unique characteristics create unique sources of synergies, potential M\&A synergies in this particular industry need to be investigated and explored further.

Table 1 presents the energy industry value chain, which is applicable to any type of energy source [14]. The energy value chain is constructed by three main sectors-upstream, midstream, and downstream. Each sector disposes individual features, attributes, and characteristics that may be employed to generate synergies during M\&A arrangements. 
Table 1. Value chain of the energy industry.

\begin{tabular}{llll}
\hline & Upstream & Midstream & Downstream \\
\hline $\begin{array}{l}\text { Prerequisites for } \\
\text { synergy exploration: }\end{array}$ & $\begin{array}{l}\text { Scale to lower costs } \\
\text { per customer }\end{array}$ & $\begin{array}{l}\text { Asset } \\
\text { optimization }\end{array}$ & $\begin{array}{l}\text { Convergence between } \\
\text { energy-related } \\
\text { services }\end{array}$ \\
\hline & - Scale synergies & \\
Synergy objective: & $\bullet$ & Scope synergies \\
& $\bullet$ & Financial synergies & \\
& & & \\
\hline
\end{tabular}

The upstream sector is defined as the exploration and production section. This segment includes searching for, recovering, and production of crude oil and natural gas from underground or underwater fields. Exploration and production segment includes drilling exploratory wells, drilling, and operating the wells. During these processes, crude oil or raw gas is recovered and brought to the surface. The upstream sector focuses primarily on commodity, low margin, and high-volume aspects and requires scale to lower costs per customer in order to explore synergies.

The midstream sector connects the upstream sector with the downstream sector. Midstream operations include elements of the upstream and downstream sectors. However, its main activities consist of transportation and marketing of wholesale products.

Therefore, focusing on the scale with physical assets is a prerequisite to explore synergies in the midstream sector. Focus on scale enables cost reduction, enhances marketing and trade capabilities, and leads to asset optimization.

The downstream sector of the energy industry encompasses refining, transportation, and marketing finished products. This part of the value chain is driven by the convergence between various energy-related services.

Using data provided by Statista [8], Figure 1 provides a forecast of worldwide electricity generation during 2018-2050, measured by different energy sources. Particularly, the table presents how much electricity has been generated by liquids, natural gas, coal, nuclear, and renewable energy sources during 2018-2020, and what are electricity generation forecasts for the upcoming three decades.

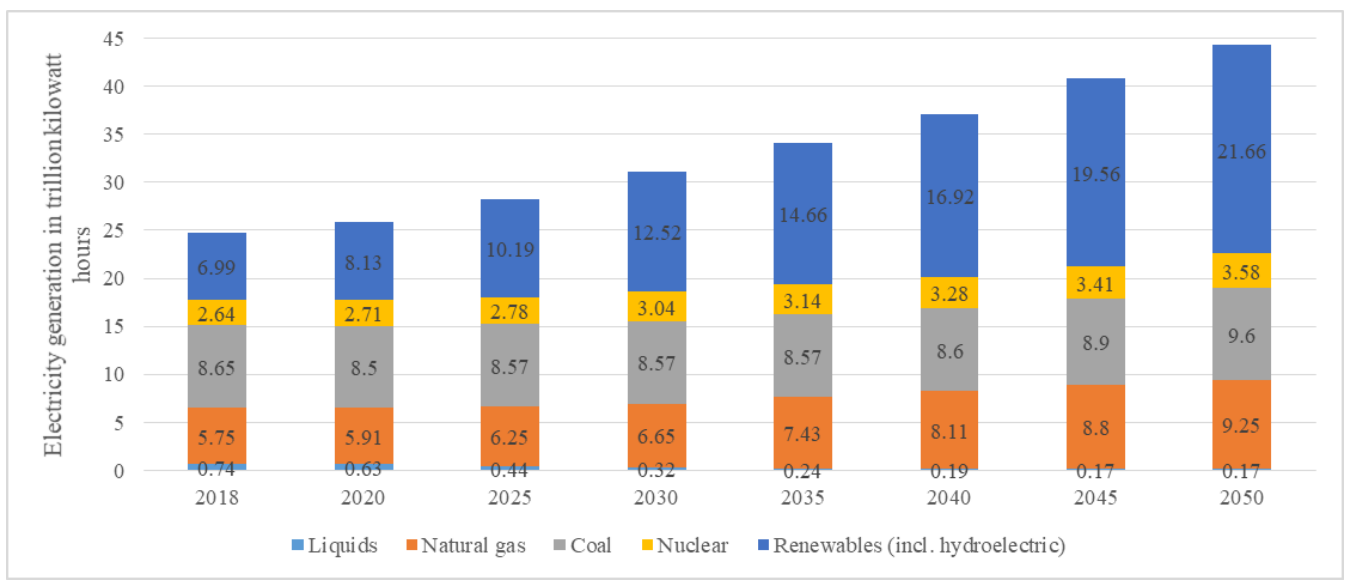

Figure 1. Forecast of worldwide electricity generation by different energy sources (in trillion kilowatt hours).

When looking into energy generation forecasts in Figure 1, several general trends of world energy development are observed. Firstly, energy sources change from fossil (high carbon) to non-fossil (low carbon). Natural gas, renewables, and nuclear power replace conventional sources such as coal [2]. This transition implies that market changes reflect the demand for green development of the ecological environment. Secondly, according 
to the data, electricity generated by each energy source will increase in the future. Total electricity generation is forecasted to almost double from 24.77 trillion kilowatt hours in 2018 to 44.26 trillion kilowatt hours in 2050 . Thirdly, renewable sources are forecasted to generate 21.77 trillion kilowatt hours in 2050, which is a $209 \%$ increase in comparison with the electricity generation of 2018. This constitutes a structural change from 28 to $49 \%$ of total electricity generation. Overall, except for coal, the current projection foresees increased consumption from all fuel sources. Considering trends and changes in electricity generation worldwide, the integration of different distribution grids shall be taken into consideration. Renewable energy sources are fluctuating. Therefore, challenges regarding their integration in the distribution grid and mitigation of electric unbalances on the grid shall be resolved [15]. However, there are several technologies that allow us to overcome these challenges and enable us to explore synergies between different energy sources. If these technologies would be advanced further, problems relating to the integration of renewable energy sources would be diminished. Overall, when different technologies with their optimized management and control perform simultaneously in a single energy system, they play a fundamental role in the energy optimization of the whole system.

Transaction premium may be defined as an important explanatory factor for the acquirers and target's revaluation in the M\&A transactions [16]. Furthermore, paid synergies and premiums are critical for the success of M\&As [16].

\section{Methodology}

Our research has adopted the framework of PESTLE analysis (Figure 2). PESTLE is a strategic management tool used in examining political, economic, social, technological, legal, and environmental factors. Within the context of our research, PESTLE is a valuable tool to determine driving forces of M\&As in the energy industry, because it is a strong analytical tool and may be used for understanding the external environment and landscape of various projects, businesses, and industries. Framework of PESTLE analysis is frequently used by business and management practitioners to investigate the environment in which they operate or plan to launch new operations [17]. Furthermore, PESTLE analysis may be used to monitor the macroeconomic or other external factors that have an impact on that environment. This approach assists to understand the dynamics of the problem. Furthermore, the PESTLE framework may be used to provoke further research directions [18]. PESTLE framework has been employed by various scholars in the field [13,17-19]. In the context of this paper, the PESTLE analysis focuses on various changes in the industry that researchers, practitioners, scholars, and policymakers should address in order to approach M\&As in the energy industry and adopt solutions that would benefit related stakeholders.

Political factors
•Determine the extent to which a government may influence the economy or the industry itself.
Economic factors
•Determine economy's performance that directly affact the market.
Social factors
• Analyze social market environment and reflect cultural trends, demographics, and population analytics.
Technological factors
•Refers to innovations in technology that may affect the operation of the industry and the market either
Legal factors
$\bullet$ Consider policies and laws which affect the industry
Environmental analysis
$\bullet$ Consider the surrounding environment.

Figure 2. Framework of PESTLE analysis. 
Considering that the motivation of the research involves investigation and analysis of developments and trends of M\&As in the energy industry, PESTLE analysis adds value to the research because it encourages a deeper understanding of the industry itself and M\&A deals within, raises alertness about recent events and global playground, and invites to exploit opportunities.

Furthermore, a sample of global M\&A deals that have occurred during the period 1995-2020 has been analyzed in our study. DataStream 5.1 database by Thomson Reuters was used to identify a sample of global companies that acquired or merged with another company during 1995-2020. The following selection criteria were established in order to gather the representative sample when working with the DataStream 5.1 database:

1. Time period: 1 January 1995-31 December 2020;

2. Form of the deal: acquisition, merger, buyback;

3. Industry: energy (specified by target ant acquires primary Standard Industrial Classification (hereinafter "SIC") codes);

4. Origin of the target and bidder is known: any region;

5. Current deal status: completed.

DataStream 5.1 database grants access to various deal characteristics (e.g., announcement and completion date, deal value, bidder and target company-specific information (e.g., size, listing status of the target, geographical scope, industries companies are active in, etc.). Analyzing a dataset of 22,428 M\&A deals with a total value exceeding USD 7.016 trillion adds value to the holistic understanding of developments and trends within the industry.

\section{Analysis}

The analysis section of the paper is divided into two sections. The first section provides the results of the PESTLE analysis and provides insights on the driving forces of M\&As in the energy industry. The second section of the research continues with the global outlook of M\&As in the energy industry.

\subsection{Driving Forces in the Energy Industry MEA Market}

Synergy benefits are one of the key assumptions before making any M\&A decision. Many M\&A deals are justified by the number of potential synergies. Therefore, analysis of driving forces in the energy industry M\&A market shall start with understanding industry-specific synergy sources and attributes. Several studies have analyzed the potential synergies of M\&As in the energy sector. Table 2 summarizes findings of studies that found empirical lines of evidence on energy sector synergies for certain energy-related M\&A deals. Christensen and Greene [20] have analyzed economies of scale in US electric power generation and concluded that a small number of large firms are not designed for efficient production. Similarly, the authors' findings support that there is little correlation between cost reduction degree and a company's growth rate. Similarly, Salvanes and Tjotta [20] support that scale synergies are applicable to small utility firms only. Farsi, Fetz, and Filippini [21] recognize that potential improvements in efficiency through unbundling should be assessed against the loss of scope economies. Curran and Spigarelli [22] conclude that technology integration and consolidation of capacities throughout the supply chain are driving forces for synergy exploration during M\&A deals in the energy industry. 
Table 2. Energy sector synergies for certain energy-related merger and acquisition (M\&A) deals.

\begin{tabular}{|c|c|c|c|c|}
\hline Study & Region & Utility Focus & $\begin{array}{l}\text { Synergy } \\
\text { Objective }\end{array}$ & Findings \\
\hline $\begin{array}{l}\text { Christensen and } \\
\text { Greene (1976) [20] }\end{array}$ & US & Power generation & Scale synergies & $\begin{array}{l}\text { Scale economies diminish with } \\
\text { increased firm size }\end{array}$ \\
\hline Sing (1987) [23] & US & $\begin{array}{l}\text { Gas/electricity } \\
\text { utilities }\end{array}$ & Scale/scope synergies & $\begin{array}{l}\text { Mean utility firm has } \\
\text { diseconomies of scale/scope }\end{array}$ \\
\hline $\begin{array}{l}\text { Salvanes and Tjotta } \\
\text { (1994) [24] }\end{array}$ & Norway & Electricity utilities & Scale synergies & $\begin{array}{l}\text { Scale synergies only for } \\
\text { small utilities }\end{array}$ \\
\hline $\begin{array}{l}\text { Burns \& Weyman Jones } \\
\text { (1996) [25] }\end{array}$ & UK & Electricity utilities & Scale synergies & Evidence for scale economies \\
\hline Filippini (1996) [26] & Switzerland & Electricity utilities & Scale synergies & $\begin{array}{l}\text { Small/medium utilities } \\
\text { experience economies } \\
\text { of density }\end{array}$ \\
\hline Yatchew (2000) [27] & Canada & $\begin{array}{c}\text { Electricity/water } \\
\text { utilities }\end{array}$ & Scale/scope synergies & $\begin{array}{l}\text { Small utility firms benefit from } \\
\text { scope synergies }\end{array}$ \\
\hline $\begin{array}{c}\text { Fraquelli, Piacenza, } \\
\text { and Vannoni (2004) [28] }\end{array}$ & Italy & $\begin{array}{c}\text { Gas/electricity/water } \\
\text { utilities }\end{array}$ & Scale/scope synergies & $\begin{array}{l}\text { Small utility firms benefit from } \\
\text { scale/scope synergies }\end{array}$ \\
\hline Kwoka (2005) [29] & US & Power distribution & Scale synergies & Scale economies are conducted \\
\hline $\begin{array}{l}\text { Farsi, Fetz, Filippini } \\
\text { (2008) }[21]\end{array}$ & Switzerland & $\begin{array}{l}\text { Electricity, gas, and } \\
\text { water utilities. }\end{array}$ & Scale/scope synergies & $\begin{array}{l}\text { Potential improvements in } \\
\text { efficiency should be assessed } \\
\text { against the loss of } \\
\text { scope economies. }\end{array}$ \\
\hline $\begin{array}{l}\text { Piacenza and Vannoni } \\
\text { (2009) [30] }\end{array}$ & Italy & Electricity & Scale synergies & $\begin{array}{l}\text { Vertical and horizontal } \\
\text { scale synergies }\end{array}$ \\
\hline $\begin{array}{l}\text { Goto, Shang, and } \\
\text { Toshiyuki (2009) [31] }\end{array}$ & US & Gas/electricity utilities & Financial synergies & $\begin{array}{l}\text { Synergies vanished for } \\
\text { multiutilities } \\
\text { after deregulation }\end{array}$ \\
\hline $\begin{array}{l}\text { Sueyoshia and Goto } \\
\text { (2011) [32] }\end{array}$ & US & Gas/electricity utilities & Operational synergies & No synergies for multiutilities \\
\hline $\begin{array}{c}\text { Fraunhoffer and } \\
\text { Schiereck (2012) [14] }\end{array}$ & Germany & Energy providers & Scale/scope synergies & $\begin{array}{c}\text { Financial synergies play a } \\
\text { minor role in the energy M\&A } \\
\text { market. Operational, } \\
\text { scale-related, and scope } \\
\text { synergies are important. }\end{array}$ \\
\hline $\begin{array}{l}\text { Curran and Spigarelli } \\
\text { (2017) [22] }\end{array}$ & EU, China & Wind and solar sectors & $\begin{array}{l}\text { Scale/operational } \\
\text { synergies }\end{array}$ & $\begin{array}{l}\text { Technology integration and the } \\
\text { consolidation of capacities } \\
\text { throughout the supply chain } \\
\text { are driving forces for } \\
\text { synergy exploration. }\end{array}$ \\
\hline
\end{tabular}

It becomes evident that no universal finding prevails in each study. On the one hand, financial synergies are not very important for energy-related M\&A deals [14]. On the other hand, it shall be observed that operational, scale-related, and scope synergies explored in power generation and distribution stages are significant for energy-related M\&A deals. Our research recognizes that the transformation of global energy markets affects M\&A efficiency and future from various perspectives [13] and has adopted the framework of PESTLE analysis, which was described in the Methodology Section of the paper. Table 3 below distinguishes between various political, economic, social, technological, legal, and environmental factors and provides results of PESTLE analysis of M\&A in the energy industry. 
Table 3. Summary of the results of the PESTLE analysis of M\&A in the energy industry.

\begin{tabular}{|c|c|c|c|c|c|}
\hline Political. & Economic & Social & Technological & Legal & Environmental \\
\hline $\begin{array}{l}\text { Political stability } \\
\text { vs. political } \\
\text { instability and } \\
\text { uncertainty } \\
\text { Restructuring in } \\
\text { the energy sector } \\
\text { and stimulating } \\
\text { energy } \\
\text { development } \\
\text { Denationalization } \\
\text { and privatization } \\
\text { State support for } \\
\text { the development } \\
\text { of renewable } \\
\text { energy } \\
\text { Implementation of } \\
\text { sustainable } \\
\text { development } \\
\text { strategies } \\
\text { Implementation of } \\
\text { energy efficiency } \\
\text { policy }\end{array}$ & $\begin{array}{l}\text { Economic growth } \\
\text { of countries } \\
\text { Tax rates, } \\
\text { Fluctuations in } \\
\text { prices of oil and } \\
\text { other commodities, } \\
\text { Instability in } \\
\text { currency exchange } \\
\text { rates } \\
\text { Liberalization of } \\
\text { the energy markets }\end{array}$ & $\begin{array}{c}\text { Increase in global } \\
\text { population size } \\
\text { Increasing middle } \\
\text { class } \\
\text { Concerns over } \\
\text { ecologization }\end{array}$ & $\begin{array}{l}\text { Improvements of } \\
\text { the electricity } \\
\text { production } \\
\text { technologies from } \\
\text { renewable energy } \\
\text { sources } \\
\text { Development of } \\
\text { deep drilling and } \\
\text { offshore oil and } \\
\text { gas extraction } \\
\text { technologies } \\
\text { Widespread } \\
\text { introduction of } \\
\text { Smart Grid } \\
\text { technologies } \\
\text { Intelligent } \\
\text { technologies Wide } \\
\text { spreading } \\
\text { robotization }\end{array}$ & $\begin{array}{l}\text { Liberalization of } \\
\text { electricity markets } \\
\text { in the EU } \\
\text { Strengthening of } \\
\text { antitrust laws } \\
\text { Implementation of } \\
\text { the standards on } \\
\text { energy } \\
\text { management } \\
\text { Legalization of the } \\
\text { energy service }\end{array}$ & $\begin{array}{c}\text { Focus on } \\
\text { sustainable } \\
\text { development } \\
\text { Paris Climate } \\
\text { Agreement } \\
\text { Increased } \\
\text { environmental } \\
\text { safety } \\
\text { requirements }\end{array}$ \\
\hline
\end{tabular}

Firstly, political factors are governed by the degree of intervention by governments in the economy and they greatly affect the conduct and performance of M\&A in the industry. From this perspective, greater political stability, denationalization and privatization, governmental support for renewable energy developments, industry restructuring, policies of demonopolization, and implementation of sustainable development strategies greatly affect the environment, scope, and outcomes of M\&As in the energy industry. Looking from a global perspective, it shall be acknowledged that political stability enables and favors the cooperation between energy companies and governments. On the other hand, political instability and uncertainty reduce the profits of energy companies. The promotion of industry M\&As is circumstanced by energy sector restructures and energy development stimulations. These trends promote the attraction of new investments and the development of energy companies. An important political factor contributing to M\&A increase is denationalization and privatization. Similarly, the policy of diversification promotes cross-border M\&As in markets where denationalization and privatization periods are ongoing. Policies of demonopolization in national energy markets increase competition and change conjuncture of the market structure. The global path toward implementation and assurance of sustainable development strategies contributes to economic growth. This also leads to an increase in M\&A transactions.

Secondly, the energy industry and M\&A deals within are affected by changes in the economic environment (e.g., economic growth, tax, interest, and exchange rates). Coronavirus has caused oil companies to face the worst oversupply in history. Supply pact by OPEC and other producers, known as OPEC+, collapsed on 6 March 2020, hastening a drop in prices that were already falling due to the coronavirus outbreak. Countries economic growth leads to growing energy demand for energy. Larger sales volumes enable increasing profits of energy firms. On the one hand, low tax rates contribute to increasing the incomes of energy companies. On the other hand, high tax rates for energy companies lead to lower incomes. Oil price fluctuations enhance investment risk and the risk of profit loss. Exchange market fluctuations increase the value of energy production from imported primary energy sources. Among other reasons, the increase in M\&A transactions is influenced by the liberalization of the energy markets. All these factors define the future 
of companies in the energy sector, affect growth strategies of the firms, and shall be taken into account when analyzing current and future prospects of $\mathrm{M} \& \mathrm{~A}$ in the energy sector.

The effect of the social factor of the energy industry refers to social changes and social stability. Increasing population leads to increased energy. Therefore, energy companies may experience larger profits. Middle-class share in developing countries is increasing. Therefore, the increasing demand for the use of renewable energy sources as automobile fuel reflects trends of ecologization and consciousness of the population regarding sustainability and social responsibility.

Technological factors reflect technological developments and innovations in the energy industry. There are various developments within the energy industry that affect the operation of the industry and M\&A deals within. Electricity production technologies are improved in the renewable energy sector. These advancements help to reduce the cost and increase profitability. Furthermore, the development of deep drilling and offshore extraction technologies reduces the cost of electricity production. These advancements enable the increase in the profits of vertically integrated businesses. The development of technologies for the extraction of shale gas, petroleum, and bituminous sands reduces costs and increases the efficiency of energy companies. The widespread introduction of smart grid technologies at different levels facilitates the optimization of the electricity supply. Optimization helps to reduce energy companies' expenditures. Usage of smart technologies and robotization of firms increases their attractiveness for potential transactions of M\&As. Overall, the list of technological factors that challenge and affect industry M\&As is broad and shall be carefully investigated.

From the perspective of legal aspects, several trends are observed. The focus on liberalization of electricity markets in the European Union stimulated activities of international energy companies. On the other hand, it shall be observed that increasing restrictions help to monopolize and increase profits of certain energy companies. Strengthened antitrust laws can reduce the profits of energy companies. The introduction of the standards on energy management at the legislative level reduces energy consumption. This leads to reduced profits for energy companies. Legalization of the energy service may reduce energy consumption, which will reduce the profits of energy companies.

Finally, the environmental factor is extremely important. There is an ongoing focus on sustainable development, which refers to the management of oil and gas resources in ways that leaves a positive economic legacy for those countries when their reserves run out. The Paris Climate Agreement on reduction of carbon dioxide emissions dated 22 April 2016 and other environmental programs of the countries promote the development of renewable energy and reduced use of gas and coal as energy sources, which will increase the share of transactions in the market for the production of electricity from renewable energy sources. On the other hand, considering that increased environmental safety requirements increase expenses, activities in the energy M\&A market may slow down.

\subsection{Global Outlook of MEA in the Energy Industry}

Figure 3 describes the annual deal value and volume of M\&As in the energy industry. Several trends may be observed from the statistics. Firstly, 22,428 M\&A deals with a total value exceeding USD 7.016 trillion have been completed during 1995-2020. Secondly, the annual deal value and volume of M\&As have fluctuated considerably. While the number of deals has been relatively stable from 1995 to 2001 (702 deals per year), the value of annual deals has increased by over 394 percent (from USD 46 billion USD in 1995 to over USD 230 billion in 2001) leading to an average deal size increasing from USD 82 million to USD 317 million. Value of deals has been the lowest from 2002 to 2004 . However, the number of deals per year has doubled in the period from 2002 to 2008. The peak of the annual deal value has been reached in 2007 and exceeded USD 414 billion. Similar annual M\&A values have been experienced in 2013 (USD 409 billion) and 2017 (USD 403 billion). 


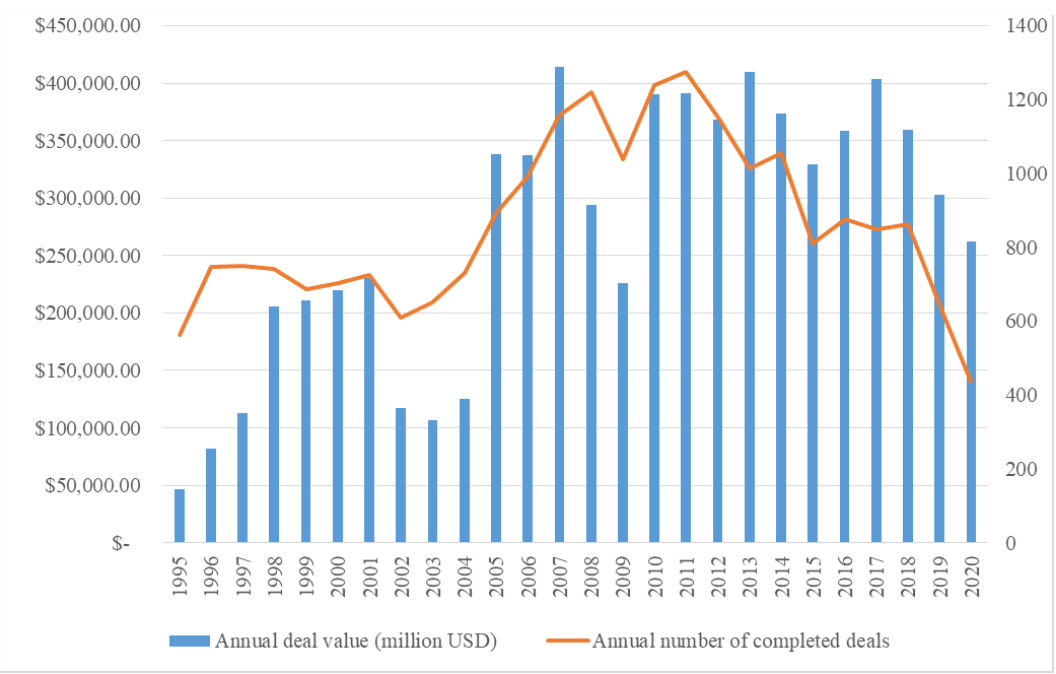

Figure 3. Annual deal value and volume of energy industry M\&A market.

Thirdly, the annual deal value has been relatively stable in the period from 2010 to 2017 and averaged USD 378 billion USD. However, it shall be observed that the number of deals has been decreasing since 2011. This leads to a critical conclusion that the average deal value has almost doubled, from an average deal value of USD 307 million in 2011 to over USD 600 million in 2020. This raises several concerns. Firstly, a reduced number of deals and increased deal value may indicate a low number of industry players competing for the market share. Moreover, this change suggests changes in market structure. Secondly, a reduced number of deals suggests that companies switch from external to internal growth strategies. Finally, the given trends raise concerns about possible overvaluations in capital markets.

Figure 4 distinguishes between domestic and cross-border M\&As. Interestingly, while the number of deals has fluctuated during 1995-2020, the percentage of domestic deals have stayed relatively stable and amounted to $69.7 \%$. Accordingly, on average, $30.3 \%$ of the deals have been cross border and involved bidding and acquired companies from different countries in the said period. However, increased volatility shall be observed in the period of 2005-2008. Specifically, the percentage of domestic deals has accumulated to $75.3 \%$ in 2005 and went down to $63.8 \%$ in 2008 .

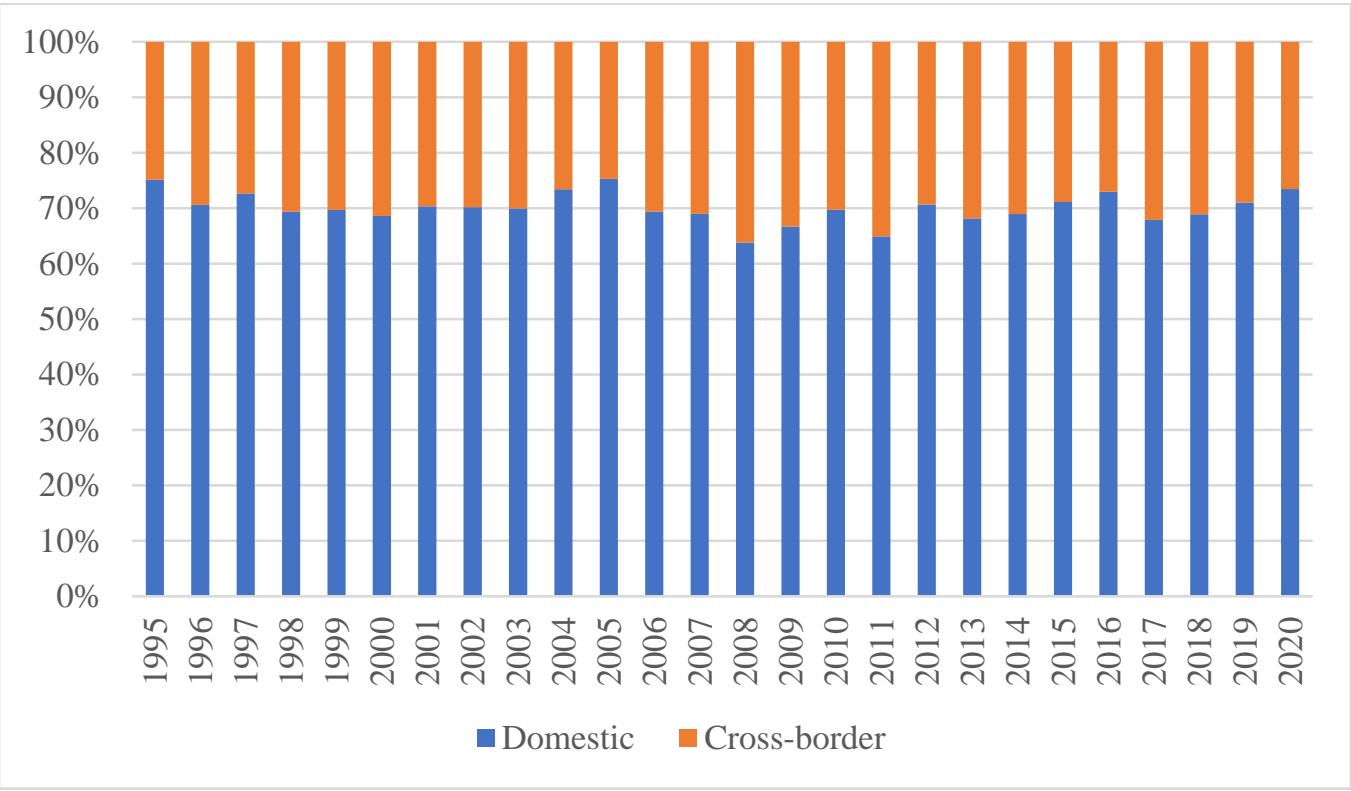

Figure 4. Dynamics of domestic vs. cross-border M\&As in the energy industry. 
Figure 5 provides insights into diversifying vs. consolidating M\&As in the energy industry. Several trends are being observed. Firstly, $65.3 \%$ of the deals completed during 1995-2020 were diversifying. Secondly, while diversifying M\&As amounted to $61.1 \%$ in 1995 , their share has increased to $81.5 \%$ in 2020 . Thirdly, while the number of diversifying M\&As was relatively stable during 1995-2011, a sharp increase of diversifying M\&As was experienced during 2012-2020.

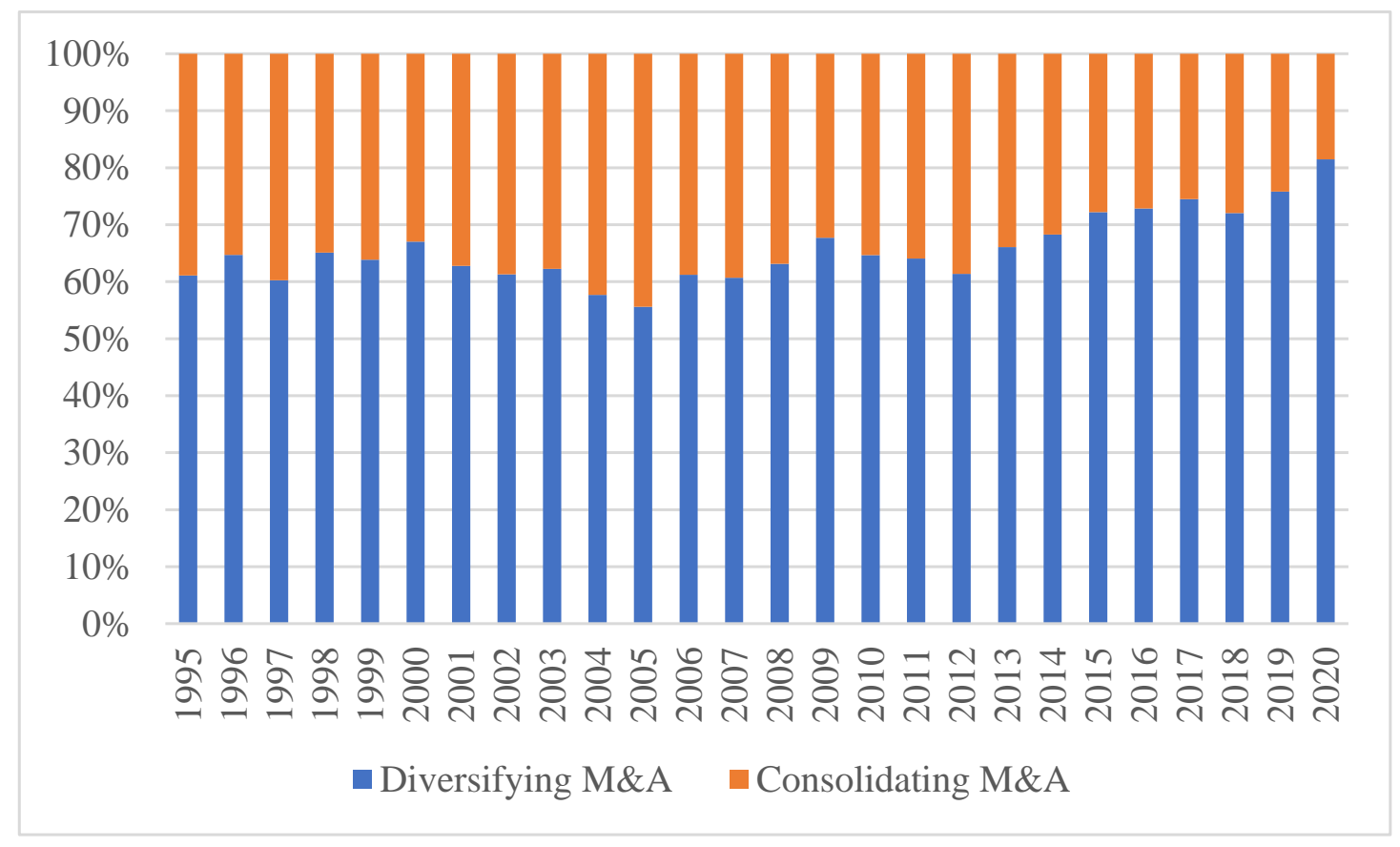

Figure 5. Dynamics of diversifying vs. consolidating M\&As in the energy industry.

Dynamics that are shown regarding diversifying vs. consolidating M\&As in the energy industry imply that companies pursue diversifying M\&As in order to expand their product and service portfolio. Given this trend, it shall be observed that bidding companies find unrelated M\&As as unlocking synergies, promoting growth, or reducing risks in other operations.

\section{Discussion}

The research was triggered by the observation that while the role and presence of $M \& A s$ in the energy industry are increasing, the purpose of the M\&A deals has changed remarkably.

Even though many companies in the energy industry have already implemented or are planning to participate in the M\&A market because this growth strategy is found to be quicker and, in many cases, cheaper than internal development or strategic alliances, empirical studies do not provide concurring results and do not unambiguously confirm that M\&A transactions generate an economic return. The value chain of the energy industry may be divided into upstream, midstream, and downstream segments with each seeking to generate scale, scope, financial, and/or operation synergies during the employment of M\&As.

Ongoing changes in the nature of energy sources imply that market changes reflect the demand for green development of the ecological environment. Renewable energy sources are fluctuating. This challenges the full integration of renewable energy sources in the distribution grid and the mitigation of electric unbalances on the grid. However, there are several technologies in the market that technically enable the exploitation of synergies between various energy networks, thus alleviating problems of renewable energy source integration. Trending focus on sustainable development, the Paris Climate Agreement 
on reduction of carbon dioxide emissions, and globally increasing environmental safety requirements are among environmental factors that shape the energy industry M\&A market.

Factors listed in the PESTLE analysis clearly signify the ongoing transformation of the global energy market. M\&A decision making, subsequent volume and value of the deals, outcomes of the transactions, etc. all reflect political, economic, social, technological, legal, and environmental factors. The most important factors are the fluctuation of commodity prices, increasing oil supply, penetration and active developments of renewable energy sources, employment of smart grid technology, which enables the reduction in transaction costs favored by flexibility and working in the optimal mode of electrical grids, and liberalization of energy markets.

To conclude our discussion, we would like to highlight that, based on our research, we may propose several future research directions. Following the framework of PESTLE analysis, we have presented political, economic, social, technological, environmental, and legal factors that shape M\&As in the energy industry. We have not focused on a specific region or sector of the industry. Therefore, further work and analysis may be directed from this perspective. When employing the DataStream 5.1 database, we have only analyzed global deals. We have neither exemplified nor distinguished different regions, states, or areas. Therefore, future research may work on and present possible correlations between different regions, states, or areas. Furthermore, our research has shown that the most significant structural changes occur in renewable sources. However, our research has not explicitly focused on M\&As in the renewable energy segment. Therefore, future research may particularly analyze M\&A in the renewable energy segment, which, in recent years, has dominated the global market for transactions in the energy sector. Research in the directions listed above may further allow the discovery of new perspectives.

\section{Conclusions}

This research analyzed and discussed the ongoing developments of M\&As in the energy industry during 1995-2020 by conducting a structured literature review, performing a PESTLE analysis, and analyzing a sample of global M\&As. Global developments in the energy industry are changing the landscape of M\&As. The research highlights the complexity by identifying various interrelationships between political, economic, social, technological, legal, and environmental factors that affect industry M\&As.

The paper acknowledges that the transformation of the global energy markets affects the current status, efficiency, and future of the industry M\&As. This research supports that the energy industry M\&A market is signified by wavelike tendencies and the cyclical nature of ongoing processes and developments development. Average M\&A deal value in the energy industry has increased from USD 307 million in 2011 to over USD 600 million in 2020, raising concerns about changing market structures and overvaluations in the capital markets. Identification of the driving forces of developments in the energy M\&A market is integral with political, economic, social, technological, legal, and environmental industry dimensions.

This paper contributes to the body of existing research on M\&As and adds to a better understanding of the study phenomenon. We believe our research perspective helps energy, international business, and management scholars and practitioners to enhance understanding of international M\&A behavior.

Author Contributions: Conceptualization, K.A. and D.Š.; methodology, K.A.; software, K.A.; validation, K.A.; formal analysis, K.A.; investigation, K.A.; resources, K.A.; data curation, K.A.; writingoriginal draft preparation, K.A.; writing — review and editing, K.A.; visualization, K.A.; supervision, D.S.; project administration, K.A.; funding acquisition, K.A. All authors have read and agreed to the published version of the manuscript.

Funding: This research was funded by the European Social Fund under the No. 09.3.3 LMT K 712 "Development of Competencies of Scientists, other Researchers, and Students through Practical Research Activities" measure. 
Institutional Review Board Statement: Not applicable.

Informed Consent Statement: Not applicable.

Data Availability Statement: Not applicable.

Conflicts of Interest: The authors declare no conflict of interest.

\section{References}

1. Freier, J. Successful Corporate Acquisitions: A Complete Guide for Acquiring Companies for Growth and Profit; Prentice Hall, Inc.: Eng-lewood Cliffs, NJ, USA, 1990; 401p, ISBN 0138605033.

2. Cainenga, Z.; Qun, Z.; Guosheng, Z.; Bo, X. Energy revolution: From a fossil energy era to a new energy era. Nat. Gas Ind. 2016, 3, $1-11$.

3. Maksimovic, V.; Phillips, G.; Yang, L. Private and Public Merger Waves. J. Financ. 2013, 68, 2177-2217. [CrossRef]

4. Mitchell, M.L.; Mulherin, J. The impact of industry shocks on takeover and restructuring activity. J. Financ. Econ. 1996, 41, 193-229. [CrossRef]

5. Harford, J. What drives merger waves? J. Financ. Econ. 2005, 77, 529-560. [CrossRef]

6. Jovanovic, B.; Rousseau, P.L. The Q-Theory of Mergers. Am. Econ. Rev. 2002, 92, 198-204. [CrossRef]

7. Servaes, H. Tobin's Q and the Gains from Takeovers. J. Financ. 1991, 46, 409-419. [CrossRef]

8. Statista Website. Available online: https://www.statista.com/statistics/238610/projected-world-electricity-generation-byenergy-source/ (accessed on 26 February 2021).

9. Rhodes-Kropf, M.; Robinson, D.T.; Viswanathan, S. Valuation waves and merger activity: The empirical evidence. J. Financ. Econ. 2005, 77, 561-603. [CrossRef]

10. Savor, P.G.; Lu, Q. Do Stock Mergers Create Value for Acquirers? J. Financ. 2009, 64, 1061-1097. [CrossRef]

11. Shleifer, A.; Vishny, R.W. Stock market driven acquisitions. J. Financ. Econ. 2003, 70, 295-311. [CrossRef]

12. Reddy, K.; Xie, E. Cross-border mergers and acquisitions by oil and gas multinational enterprises: Geography-based view of energy strategy. Renew. Sustain. Energy Rev. 2017, 72, 961-980. [CrossRef]

13. Galperina, L.; Klen, Y. Global Trends of International Mergers and Acquisitions in the Energy Sector. Int. Econ. Policy 2017, 26, 43-68.

14. Fraunhoffer, R.; Schiereck, D. Consolidation of the energy sector, potential synergies, and realized shareholder value-Survey and new insights from top managers' perceptions. Probl. Perspect. Manag. 2012, 10, 81-92.

15. Badami, M.; Fambri, G. Optimising energy flows and synergies between energy networks. Energy 2019, 173, 400-412. [CrossRef]

16. Moeller, S.B.; Schlingemann, F.P.; Stulz, R.M. Firm size and the gains from acquisitions. J. Financ. Econ. 2004, 73, 201-228. [CrossRef]

17. Yudha, S.W.; Tjahjono, B.; Kolios, A. A PESTLE Policy Mapping and Stakeholder Analysis of Indonesia's Fossil Fuel Energy Industry. Energies 2018, 11, 1272. [CrossRef]

18. Mytilinou, V.; Kolios, A.J.; Di Lorenzo, G. A comparative multi-disciplinary policy review in wind energy developments in Europe. Int. J. Sustain. Energy 2017, 36, 754-774. [CrossRef]

19. Achinas, S.; Horjus, J.; Achinas, V.; Euverink, G.J.W. A PESTLE Analysis of Biofuels Energy Industry in Europe. Sustainability 2019, 11, 5981. [CrossRef]

20. Christensen, L.R.; Greene, W.H. Economies of Scale in U.S. Electric Power Generation. J. Polit. Econ. 1976, 84, 655-676. [CrossRef]

21. Farsi, M.; Fetz, A.; Filippini, M. Economies of Scale and Scope in Multi-Utilities. Energy J. 2008, 29, 123-143. [CrossRef]

22. Curran, L.; Lv, P.; Spigarelli, F. Chinese investment in the EU renewable energy sector: Motives, synergies and policy implications. Energy Policy 2017, 101, 670-682. [CrossRef]

23. Sing, M. Are Combination Gas and Electric Utilities Multiproduct Natural Monopolies? Rev. Econ. Stat. 1987, 69, 392. [CrossRef]

24. Salvanes, K.G.; Tjøtta, S. A Test for Natural Monopoly with Application to Norwegian Electricity Distribution. Rev. Ind. Organ. 1998, 13, 669-685. [CrossRef]

25. Burns, P.; Weyman-Jones, T.G. Cost Functions and Cost Efficiency in Electricity Distribution: A Stochastic Frontier Approach. Bull. Econ. Res. 1996, 48, 41-64. [CrossRef]

26. Filippini, M. Economies of scale and utilization in the Swiss electric power distribution industry. Appl. Econ. 1996, 28, 543-550. [CrossRef]

27. Yatchew, A. Scale economics in electricity distribution: A semiparametric analysis. J. Appl. Econom. 2000, 15, 187-210. [CrossRef]

28. Fraquelli, G.M.; Piacenza, D. Vannoni. Scope and scale economies in multi-utilities: Evidence from gas, waste and electricity combinations. Appl. Econ. 2004, 36, 2045-2057. [CrossRef]

29. Kwoka, J.E. Electric power distribution: Economies of scale, mergers, and restructuring. Appl. Econ. 2005, 37, 2373-2386. [CrossRef]

30. Piacenza, M.; Vannoni, D. Vertical and horizontal economies in the electrical utility industry: An integrated approach. Ann. Public Coop. Econ. 2009, 80, 431-450. [CrossRef] 
31. Sueyoshi, T.; Goto, M.; Shang, J. Core business concentration vs. corporate diversification in the US electric utility industry: Synergy and deregulation effects. Energy Policy 2009, 37, 4583-4594.

32. Sueyoshi, T.; Goto, M. Operational synergy in the US electric utility industry under an influence of deregulation policy: A linkage to financial performance and corporate value. Energy Policy 2011, 39, 699-713. [CrossRef] 